\title{
Environmental Health Risk Analysis of Paraquat Exposure in Palm Oil Plantations
}

\author{
Maksuk $^{1,2}$, Tan Malaka ${ }^{3}$, Suheryanto $^{4}$, Abu Umayah ${ }^{5}$ \\ ${ }^{1}$ Environmental Science Program, Sriwijaya University, Indonesia \\ ${ }^{2}$ Health Polytechnic, Palembang, Indonesia \\ ${ }^{3}$ Faculty of Medical, Sriwijaya University, Indonesia \\ ${ }^{4}$ Faculty of Mathematical and Natural Science, Sriwijaya University, Indonesia \\ ${ }^{5}$ Faculty of Agriculture, Sriwijaya University, Indonesia
}

\section{Article Info}

Article history:

Received Aug 30, 2016

Revised Nov 1, 2016

Accepted Nov 16, 2016

\section{Keyword:}

Palm oil plantation

Paraquat

Risk quotient

Soil

Water

\begin{abstract}
Paraquat (1, 1'-dimethyl-4, 4'-bipyridylium dichloride) is a highly toxic herbicide. Recently, Paraquat is still used widely in the plantations area, mainly in palm oil plantations. Paraquat application continuously can be increased Paraquat concentration and contaminated in soil and water. This study aimed was to analysis Paraquat exposure in environmental media water and soil, and the calculation of risk quotient of Paraquat in palm oil plantation. The study design of this research was a cross sectional with the laboratory examination Paraquat concentrations in soil and water. Soil and water samples taken by grab sampling with random composites. Water samples were taken from three sources in palm oil plantations area. Whereas soil samples were taken at a depth of $0-10 \mathrm{~cm}$ (top soil) and the number of soil samples as much as 5 samples. Furthermore, the risk quotient of Paraquat concentration in the water used in the palm oil plantation. The laboratory tests of Paraquat concentration were in water and soil with gas chromatography. The results of laboratory tests showed that Paraquat concentration in water samples were found between $<0.005$ to $0.01 \mathrm{mg} / \mathrm{l}$ and Paraquat concentration in soil samples were found between $<0.005$ to 0.08 $\mathrm{ppm}$. The calculation of risk quotient was $0.058 \mathrm{mg} /$ body weight/day. Although, the calculated of risk quotient showed less than one. Therefore, prior to use the water must be treatment first. While the recommended water to consumption as much as 2 liters/day for a $55 \mathrm{~kg}$ body weight to Indonesian workers.
\end{abstract}

Copyright $\odot 2016$ Institute of Advanced Engineering and Science. All rights reserved.

\section{Corresponding Author:}

Maksuk,

Environmental Science Program, Sriwijaya University, Indonesia,

Health Polytechnic, Palembang, Indonesia,

Jalan Merdeka 10A, Palembang, South Sumatera, Indonesia.

Email: maksuk@poltekkespalembang.ac.id

\section{INTRODUCTION}

The use of herbicides is currently the most widely used in the plantation area. One of them is the active ingredient Paraquat. Paraquat is classified as restricted use pesticides in Indonesia [1]. However, Paraquat is still widely used freely on the estate to control weeds and are not considered strictly use in the field. Paraquat is applied partially absorbed by weeds and get into the soil and water. It can be absorbed by soil colloids, so can be contaminated the soil and water [2]. In addition to the results of laboratory test Paraquat concentration in water can be used to predict the risk quotient in palm oil plantations, caused the water were using by workers. 


\section{RESEARCH METHOD}

The study design of this research was a cross sectional with the laboratory examination Paraquat concentrations in soil and water.

\subsection{Water Sampling}

Water sampling was groundwater in the palm oil plantation area of SAL Company Banyuasin. There are three sources of water were taken as samples. Samples collected by grap sampling with random composites. The eequipment for water sampling were containers, rope with incorporating weights, thermometer, $\mathrm{pH}$ meter, cool box and ice pack. Water samples were taken as much as 1 liter for each area, and then entered into container and stored in a cool box. Further, water samples sent to the laboratory to analysis. Methods of analysis were using 18-GC-1/F-MU/SMMAAS.

\subsection{Soil Sampling}

Soil sampling on top soil with a depth between 0-10 $\mathrm{cm}$. Samples collected by grap sampling with random composites. Equipment for soil sampling such as: hoe, bucket, scale, plastic bags. Soil samples were taken as much as $1 \mathrm{~kg}$ for each area, and then, samples were stored in a cool box. Furthermore, the soil samples sent to the laboratory. Methods of analysis were using 18-GC-1/F-MU/SMMAAS.

The sampling procedures, namely:

- Determine the location of the area

- Cleaned the grass, stones or gravel, the rest of the crops is in the surface area.

- The soil samples were taken using a hoe or shovel with a depth between $0-10 \mathrm{~cm}$.

- All soil samples were mixed and stirred evenly in a bucket, then cleaned of residual plant or root. After the soil was cleaned and well mixed, samples were taken weighing approximately $1 \mathrm{~kg}$ and put into a plastic bag.

- Labelling the outside and inside of each soil sample.

\section{RESULTS AND ANALYSIS}

\subsection{Paraquat Concentrations in Water}

The results of laboratory test of Paraquat concentrations in water can be explained in Table 1. Based on Table 1, the results of Paraquat concentrations in water between $<0.005$ to $0.01 \mathrm{mg} / \mathrm{L}$. Paraquat application continuously and long term can be increased Paraquat concentration in water in palm oil plantation. This was caused by Paraquat deposited on the surface of the soil or the seeds after application, and also Paraquat residues on the surface of the soil or seeds can be transported by water to pour into the canal or other water sources in palm oil plantations.

Table 1.The Results of Laboratory Test of Paraquat Concentration in Water in Palm Oil Plantation Banyuasin District

\begin{tabular}{lccccc}
\hline Parameter & Unit & Groundwater & $\begin{array}{c}\text { Sample Locations } \\
\text { Canal Water }\end{array}$ & \multicolumn{2}{c}{$\begin{array}{c}\text { Water reservoirs } \\
\text { Allowed } \\
\text { Levels }\end{array}$} \\
\hline $\mathrm{pH}$ & ${ }^{\circ} \mathrm{C}$ & 8.12 & 6.6 & 3.4 & $6.5-8.5[3]$ \\
Temperature & $\mathrm{mg} / \mathrm{L}$ & 25 & 29,4 & 25 & $\pm 3[4]$ \\
Paraquat Concentration & & 0.01 & $<0.005$ & $<0.005$ & $0.01[4]$ \\
\hline
\end{tabular}

Paraquat is a pesticide cationic highly soluble in water, making it possible to leach by rain water or water channels in the plantation area. Paraquat solubility in water was quite high at $20^{\circ} \mathrm{C}$ with a $\mathrm{pH}$ of 7.2 and 9.2 and the solubility in water of Paraquat $620 \mathrm{~g} / \mathrm{L}$ [5]. In addition, Paraquat concentration in the water can be absorbed by the particles and sediment, where the half-life of Paraquat in the water between 2 to 820 years, depending on the sunlight and the water depth [6]. Paraquat concentration found in groundwater $>18.9 \mathrm{mg} / \mathrm{L}$ in Thailand [7], and in Andalusia, Spain found in surface water and groundwater [8]. Paraquat residues found in drinking water $>0.1 \mathrm{mg} / \mathrm{L}$ in some samples, ranging up to $5.3 \mathrm{mg} / \mathrm{L}$ in St. Lucia Caribbean [9]. In addition, research conducted in the waters of a flood of Lubuk Lampam Swamp, South Sumatra reported that Paraquat concentration was relatively low with averages of $0.004 \mathrm{mg} / \mathrm{L} \mathrm{[10]}$. While Paraquat concentration carried out in two seasons, was found in water samples taken upstream to downstream, the two summers of 0.13 to $7.13 \mathrm{mg} / \mathrm{L}$ and the winter of between 0.07 to $13.05 \mathrm{mg} / \mathrm{L}$ [11]. The concentrate of herbicide actives ingredient found in the surface water in the agricultural area Padavi-Srivura 
in Sri Lanka is at a very low level and has undetectable levels of herbicide active ingredient [12]. The results of laboratory test of Paraquat concentrations in soil can be explained in Table 2.

Table 2.The Results of Laboratory Test of Paraquat Concentration in Soil

\begin{tabular}{|c|c|c|c|c|c|c|c|}
\hline \multirow[b]{2}{*}{ Parameter } & \multirow[b]{2}{*}{ Unit } & \multicolumn{5}{|c|}{ Sample Locations } & \multirow{2}{*}{$\begin{array}{c}\text { The } \\
\text { maximum levels } \\
\text { allowed }\end{array}$} \\
\hline & & $\begin{array}{c}\text { Nurseries } \\
\text { Area }\end{array}$ & Devise 1,2 & Devise 3 & Devise 4 & Devise 5 & \\
\hline $\mathrm{pH} \mathrm{H}_{2} \mathrm{O}$ & & 4.44 & 4.86 & 4.04 & 3.87 & 4.90 & \\
\hline Paraquat Concentration & & $<0.005$ & 0.04 & $<0.005$ & 0.08 & 0.06 & $22[13]$ \\
\hline
\end{tabular}

Based on Table 2, paraquat concentration in the soil was found between $<0.005-0.08 \mathrm{ppm}$, the soil in the palm oil plantations as acid classified. Adsorption of Paraquat in the soil affected the soil acidity. Adsorption of Paraquat on 11 samples in clay and clay loam were 4.08 and $4.05 \mu \mathrm{g} / \mathrm{g}^{-1}$, whereas Paraquat higher adsorption at high $\mathrm{pH}$ and adsorption decreases with a decrease in $\mathrm{pH}$ [14].

Paraquat residues in soil can be affected by the frequency of spraying, the concentrations used, wind direction, and soil particles. Paraquat can bond easily on clay and organic matter, the absorption increases with the content of clay particles, Paraquat residue was found in the soil between $<0.2$ to $15 \mathrm{mg} / \mathrm{kg}$ [5]. Paraquat applications continuously for long term can lead to increased Paraquat concentration in the soil, so it may be exceed the maximum value allowed. Paraquat is relatively stable in temperature, pressure and $\mathrm{pH}$ is normal, making it possible to be longer in the soil. Paraquat can bind strongly to soil particles for a long term in the inactive condition, the half-life of Paraquat in soil about 644 days [13] or more than 20 years [6].

The studied in Pelaihari with nine soil samples, 3 of them were detected containing Paraquat between 0.088 to $1.080 \mathrm{mg} / \mathrm{kg}$ dry weight soil [15]. Paraquat concentration also found in clay loam to a depth of $15 \mathrm{~cm}$, the maximum residual concentration of Paraquat was detected was 2,783 mg/kg [16], but Paraquat was found in soil layer $10-20 \mathrm{~cm}$ after first day applications and up to 2 weeks after application, after that Paraquat was only found in soil layer $0-10 \mathrm{~cm}$ [17]. Paraquat concentration was found on top soil samples in the summer between 3.33 to $8.28 \mathrm{mg} / \mathrm{kg}$ dry weight soil and in the winter Paraquat concentrations was found between $1.30-9.15 \mathrm{mg} / \mathrm{kg}$ dry weight [10].

The studied in Thailand reported that accumulation Paraquat lower in the soil layer $0-5 \mathrm{~cm}$ and in the soil layer 0-10 cm in clay columns laboratory experiments, but Paraquat degradation faster on land than on laboratory experiments, in some experiments spraying, Paraquat residues in soil was found between $22-58 \mathrm{mg} / \mathrm{kg}$, Paraquat residue in soil was very slowly redistributed [7].

The experiments using vineyards soil in Spain found approximately 70-90\% Paraquat was absorbed in the soil [18].The studied in the filtrate of soil in Kupang reported that sunlight can be increased Paraquat degradation rate was greater than Paraquat degradation due to the influence of soil materials and microorganisms [19]. Paraquat is an herbicide bio resistant where it is difficult biodegradable and relatively stable in temperature, pressure and $\mathrm{pH}$ normal, Paraquat concentration in soil is more stable when entering the soil [19], and also Paraquat is very persistent in soil [20].

Paraquat is a herbicide cationic, as herbicide cationic, Paraquat will be ionized in soil solution and formed a divalent cation with a positive charge that is distributed around the molecule, and thereby potentially being exchanged cation in the soil. Paraquat can react and be bound by the two reactive groups of soil organic colloids, possibly by ion COO, O-phenolic, a combination of both, or a combination of one of these ions with free radicals [21]-[2].

\subsection{The Calculation of the Risk Quetiont (RQ)}

Before calculating the risk quetiont, the first step was to calculate intake of Paraquat into the body, using the formula: [22]

$$
\begin{aligned}
I_{n c} & =\frac{C \times R \times f_{E} \times D_{1}}{W_{b} \times t_{\text {ayg }}} \\
& =\frac{0.01 \mathrm{mg} / \mathrm{L} \mathrm{x} 2 \mathrm{~L} / \text { days } 350 \text { days } \times 30 \text { years }}{55 \mathrm{~kg} \text { weight } \times 30 \text { years } \times 365 \text { days) }} \\
& =0.00035 \mathrm{mg} / \mathrm{kg} / \mathrm{hr}
\end{aligned}
$$

The formula can be explained that $\mathrm{I}_{\mathrm{nc}}$ is intake non carcinogenic, $\mathrm{C}$ is Paraquat concentrations in water $(\mathrm{mg} / \mathrm{L}), \mathrm{R}$ is the rate of intake per day, $\mathrm{f}_{\mathrm{e}}$ is frequency of exposure (days/year), $\mathrm{D}_{\mathrm{t}}$ is duration of 
exposure (30 years for non carcinogenic substance), $\mathrm{W}_{\mathrm{b}}$ is weight of Indonesian workers i.g. $55 \mathrm{~kg}, \mathrm{t}_{\mathrm{avg}}$ is average time period $(\mathrm{D} \times 365$ days/year).

Acute Reference Dose (ARfD) for Paraquat was $0,006 \mathrm{mg} / \mathrm{kg}$ weight/day [22]. Acute RfD estimated of the food or drinking water, in this case the concentration of Paraquat in the data results of the water used to fresh water is used also for drinking by workers in the palm oil plantations was $0.01 \mathrm{mg} / \mathrm{L}$. Furthermore, calculated the risk quetiont with formula [22]:

$$
\begin{aligned}
R Q & =\frac{I n k}{R f D} \\
& =0.058 \mathrm{mg} / \text { weight } / \text { day }
\end{aligned}
$$

The result of Risk Quetiont was $0.058 \mathrm{mg} /$ bodyweight/day, it was still within safe limits caused $\leq 1$, hence for workers with 55 body weight may be consumed as much as 2 liters of water per day.

Paraquat is classified as non-carcinogenic chemicals group [19]. The results showed the Risk Quetiont (RQ) of Paraquat was still within safe limits, where RQ $<1$. The Risk Quetiont (RQ) of Paraquat in the body varies and depends on the weight of workers. Acute reference dose (ARfD) referred for short term exposure. ARfD for Paraquat was $0.006 \mathrm{mg}$ cation $/ \mathrm{kg}$ body weight [22]. Paraquat concentrations intake into the body of workers was not only based on the ADI or ARfD. However, workers exposure to Paraquat and the risks require an assessment based on the primary route of exposure. Exposure can be through the skin when dilution and also swallowed or inhaled droplets when spraying in palm oil plantation areas [23].

\section{CONCLUSION}

Paraquat was found in the water in palm oil plantations is equal to the allowed maximum of 0.01 $\mathrm{mg} / \mathrm{L}$, but Paraquat concentrations in water and soil can be increased if it is used continuously in the palm oil plantation areas. The calculation of Risk Quetiont (RQ) was <1. However, the risk quetiont could be increased due to continuous use of Paraquat. Therefore, to reduce Paraquat concentration in the water, the water must be treatment before use. In addition the application Paraquat in palm oil plantations should be closely monitored so as not to contaminate soil and water as well as the area around the plantation.

\section{ACKNOWLEDGEMENTS}

The author would like to thank The Environmental Science Program of Sriwijaya University, Management of PT. SAL and Staffs in Banyuasin District and Government of South Sumatera Province.

\section{REFERENCES}

[1] The Regulation of the Agriculture Minister No. 01/Permentan/OT. 140/1/2007 on the List of Prohibited Pesticide Active Ingredients and Pesticides Limited.

[2] Anonym, "Herbicide absorption process," 2011. http://jaringcell.blogspot.com/2010/03/.

[3] Health Canada, "Guidelines for Canadian Drinking Water Quality-Summary Table. Water and Air Quality Bureau, Healthy Environments and Consumer Safety Branch, Ottawa, Ontario," 2014.

[4] Regulation of Health Minister No. 416, "About Terms and Water Quality Monitoring," 1990

[5] European Commission (EC), "Review report for the active substance Paraquat. Health \& Consumer Protection Directorate-General, Brussels," 2003.

[6] M. Watts, "Paraquat. PANAP (Pesticide Action Network Asia \& Pacific)," 2011.

[7] W. Amondham, et al., "Paraquat adsorption, degradation, and remobilization in tropical soils of Thailand," Journal of Environmental Science and Health, vol. 41, pp. 485-507, 2006.

[8] J. L. Vidal, et al., "Application of internal quality control to the analysis of quaternary ammonium compounds in surface and groundwater from Andalusia (Spain) by liquid chromatography with mass spectrometry," Journal of Chromatography, vol/issue: 1050(2), pp. 179-184, 2004.

[9] N. Boodram, "The fate of agro-chemicals in the land water interface, with reference to St Lucia and the wider Caribbean, Impact and amelioration of sediment and agrochemical pollution in Caribbean coastal waters, project reports (R7668)," report 4, St. Lucia, West Indies, 2002.

[10] D. Jubaedah, et al., "Water Quality Characteristics and Estimation of Ecobiological Risk of Herbicide in Lubuk Lampam Floodplain, South Sumatera," Jurnal Manusia dan Lingkungan, vol/issue: 22(1), pp. 12-21, 2015.

[11] P. Pataranawatab, et al., "Paraquat Contaminations in the Chanthaburi River and Vicinity Areas, Chanthaburi Province Thailand," Journal of Science, Technology, and Humanities, vol/issue: 10(1), pp. 17-24, 2012.

[12] C. Jayasumana, et al., "Drinking well water and occupational exposures to Herbicides is associated with chronic kidney disease, in Padavi-Sripura, Sri Lanka," Bio Med Central, vol/issue: 14(6), pp. 2-10, 2015. 
[13] Nova Scotia Environment, "Environmental Quality Standards for Contaminated Sites Rationale and Guidance Document," 2014.

[14] H. Mohammed, et al., "Adsorption study of ${ }^{14} \mathrm{C}$-paraquat in two Malaysian agricultural soils," Environ Monit Assess, vol. 176, 43-50, 2010.

[15] D. J. Jaya, et al., "Paraquat Residue in Maize Lands: Case in Tanah Laut Regency, Indonesia," Open Access Scientific Reports, vol/issue: 1(11), 2012.

[16] Y. C. Wong, et al., "Determination of Paraquat (Herbicide) Residue Level in Sandy Clay Loam Soil Using High Performance Liquid Chromatography,” Journal of Basic \& Applied Sciences, vol. 9, pp. 566-577, 2013.

[17] M. P. Moure, et al., "Competitive and non-competitive adsorption, desorption of Paraquat, diquat and difenzoquat in vineyard-devoted soils," J Hazard Mat, vol/issue: 178(1-3), pp.194-201, 2010.

[18] H. E. Wogo, et al., "Kinetics study of Paraquat degradation (1,1-dimetil-4,4-bipiridilium) in agriculture soil Kupang District," Media Exacta, vol/issue: 10(2), 2010.

[19] EPA, "Environmental Protection and Toxic Substances, Paraquat Dichloride," 1997.

[20] US EPA, "Risks of Paraquat use to federally threatened California red-legged frog (Rana aurora draytonii). Pesticide Effects Determination. Environmental Fate and Effects Division," 2009.

[21] Z. Muktamar, et al., "Paraquat Adsorption by Ultisol and Entisol Inorganic Materials at Various Concentration," Jurnal Ilmu - Ilmu Pertanian Indonesia, vol/issue: 5(2), pp. 40-47, 2003.

[22] Food and Agriculture Organization of the United Nations (FAO), "Pesticide residues in food: report of the 2003 Joint FAO/WHO Meeting of Experts, Rome," 2004.

[23] C. Wesseling, et al., "Unintentional fatal Paraquat poisonings among agricultural workers in Costa Rica: a report of fifteen cases," American Journal of Industrial Medicine, vol/issue: 32(5), pp. 433-441. 1997. 